\title{
Optimum time interval and frequency of glyphosate application for weed control in plantain (Musa sp.)'
}

\author{
Lii-Chyuan Liu and José Rodríguez-García
}

\begin{abstract}
A field trial was conducted at the Corozal Substation, to determine the effect of two time intervals (6 and 12 weeks) and four frequencies (once, twice, three and four times) of glyphosate application on weed control, phytotoxicity and yield of plantain (Musa acuminata $\times$ M. balbisiana AAB) throughout a planting cycle. The effectiveness of glyphosate at $1 \%$ increased with reduced time interval and increased frequency of application. Plantain injury was more pronounced with increased time interval and increased number of applications. The maximum yields in terms of number and weight of fruits were obtained with three applications at a 6-week interval from planting onward. The lowest number and weight of fruits were obtained in the non-weeded check. On the basis of weed control, phytotoxicity and yield data, optimum time interval and frequency of glyphosate application during a planting-to-harvest cycle was three applications of glyphosate af $1 \%$ every 6 weeks.
\end{abstract}

\section{INTRODUCTION}

In a previous investigation, Liu et al. ${ }^{3}$ demonstrated the excellent control of weeds by glyphosate in two plantain field experiments. As a consequence of our research efforts, glyphosate had been authorized for use in Puerto Rico under Federal Insecticide, Fungicide and Rodenticide Act Section 24(c). More recently a full registration of glyphosate for use in plantain has been granted by the Environmental Protection Agency.

Plantain is planted locally all year round. The registered preemergence herbicides such as ametryn and diuron do not function effectively during the dry season of the year. Consequently, some farmers prefer to use glyphosate exclusively for postemergence control of weeds. Information concerning the optimum time interval and frequency of glyphosate application for weed control in plantain is lacking in Puerto Rico and elsewhere. However, the frequency of paraquat application in plantain was established by Almodóvar. He reported that six applica-

${ }^{1}$ Manuscript submitted to Editorial Board 22 June 1987.

"Plant Physiologist and Assistant Agronomist, respectively, Agricultural Experiment Station, University of Puerto Rico, Mayagüez Campus, Río Piedras, P. R. 00928.

${ }^{3}$ Liu, L. C., Rodríguez-García and N. Semidey-Laracuente, 1981. Glyphosate for weed control in platains. J. Agric. Univ. P. R. 65 (4): 317-25.

"Almodóvar, L. A. 1977. Control of weeds in crops of economic value. Ann. Prog. Rep. Agrie. Exp. Stn., Univ. P. R., Mayagüez Campus, Río Piedras, P. R.. 
tions of paraquat at the rate of $2.34 \mathrm{~L} /$ ha provided the best weed control performance and highest fruit production. The present study was conducted to determine the effect of different time intervals and frequencies of glyphosate application on weed control, phytotoxicity and yield of plantain.

\section{MATERIALS AND METHODS}

A field trial was conducted at the Corozal Substation, Corozal, Puerto Rico in 1981 and 1982. The soil was a Corozal clay, Aquic, Tropudults, clayey, mixed, isohyperthermic with a soil $\mathrm{pH}$ of 5.7 and organic matter content of 2.5\%. Corms of Maricongo cultivar were planted January 21, 1981. Each plot was $5.5 \times 7.3 \mathrm{~m}$ with 12 plantain plants. Glyphosate at $1 \%$ was applied to the weeds every 6 and 12 weeks. Within each time interval, we included four application frequencies: once, twice, three and four times. Glyphosate, sprayed directly to weeds only, was applied with a conventional knapsack sprayer. The spray volume ranged from 468 to $986 \mathrm{~L} / \mathrm{ha}$ depending on the weed population and growth. Fertilization and pest control practices were performed in accordance with recommended practices for plantain and banana ${ }^{5}$. Weed control ratings and phytotoxicity evaluations were made periodically. The weeded checks were hand-hoed three times at approximately every 2 months from planting onward. The marketable bunches were harvested when the fruits reached mature/green stage, about 12 to 18 months after planting. Each bunch was weighed and the number of marketable fruits counted.

\section{RESULTS AND DISCUSSION}

The predominant weed species included guinea grass (Panicum maximum Jacq.) para grass [Brachiaria purpurascens (Raddi) Henr.], wild bush bean [Macroptilium lathyroides (L.) Urban], bermuda grass [Cynodon dactylon (L.) Pers.], jungle rice (Echinochloa colonum (L.) Link.], crabgrass [Digitaria sanguinalis (L.) Scop.], pigweed (Amaranthus dubius Mart.), Mexican weed [Caperonia palustris (L.) St. Hil.], spurge (Euphorbia heterophylla L.), spreading dayflower (Commelina diffusa Burm. f.) and morning glory [Ipomoea tiliaceae (Willd.) Choisy]. Table 1 shows the effectiveness of different time intervals and frequencies of glyphosate application on weed control and their phytotoxicity effect on plantain. Average weed control was poor with a single application regardless of the time from planting to application. Weed control improved with applications of glyphosate every 6 weeks, but was still better with three applications of glyphosate every 6 weeks. Four applications of glyphosate every 6 weeks controlled weeds best. However, as the time interval was extended to 12 weeks, two applications of glypho-

${ }^{6}$ Estación Experimental Agrícola, 1986. Conjunto Tecnológico para la Produceión de Plátanos y Guineos, Univ. P. R. 
TABLE 1.-Effect of different intervals and frequencies of glyphosate application on weed control and phytotoxocity of plantain at the Corozal Substation

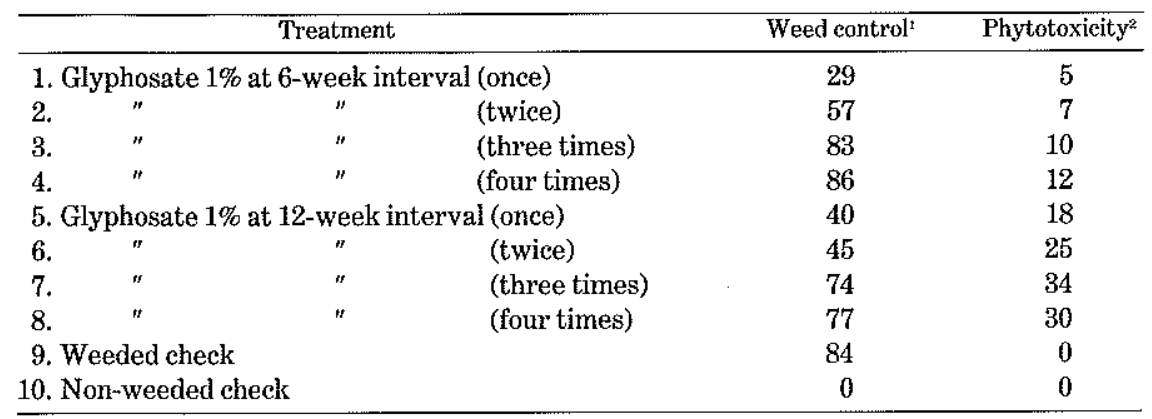

${ }^{1}$ Weed control ratings are based on a scale of 0 to 100 , where $0=$ no control; $100=$ complete control. Each figure is an average of four observation dates.

${ }^{2}$ Phytotoxicity evaluations are based on a scale of 0 to 100 , where $0=$ no phytotoxicity; $100=$ completely affected. Each figure is an accumulated average of four observation dates.

sate controlled weeds only fairly. Three or four applications improved weed control somewhat, but did not control weeds as well as applications every 6 weeks.

Table 1 also shows the phytotoxicity of glyphosate to plantain as influened by different time intervals and frequencies of application. Apparently, plantain injury increased with increasing time interval and frequency of glyphosate application. Weeds were considerably more vigorous at the 12 -week interval than at the 6 -week interval. Under these conditions, it was difficult to apply glyphosate only to weeds without injuring the crop.

The maximum yield in terms of number of marketable fruits and weight was obtained from plantains grown on plots treated with three applications of glyphosate at 6-week interval, during the planting-to-harvest cycle (table 2). However, none of the herbicide treatments significantly affected the production of fruits. All weed control treatments, including the weeded checks, averaged 59,664 fruits/ha. On the other hand, only 24,225 fruits/ha were harvested from the non-weeded treatment. No particular trend could be established with respect to the effect of the number of glyphosate applications on the weight of fruits (table 2). When the herbicide was applied once and three times at 6- and 12-week intervals, respectively, the weight of fruits was significantly reduced. The low yield obtained when the glyphosate was applied only once throughout the entire crop cycle could be attributed to poor weed control (table 1). The reduced yield experienced when glyphosate was applied three times at 12-week interval might be caused by the observed increase in crop injury (table 1). Except for the non-weeded checks all treatments yielded fruits of exceptional size. 
TABLE 2.-Effect of different intervals and frequencies of glyphosate application on fruit production of plantain at the Corozal Substation

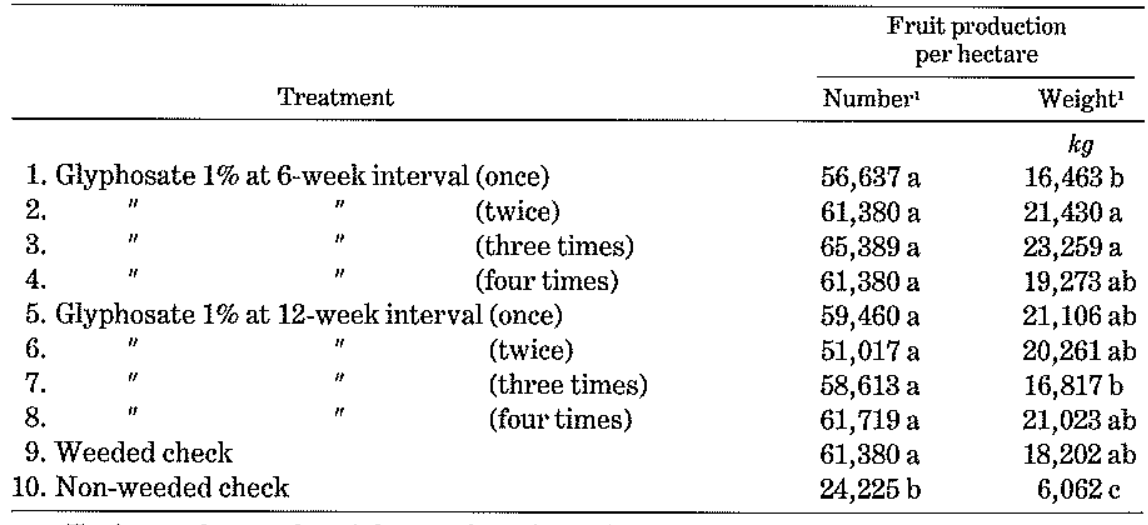

${ }^{1}$ Fruit number and weight are based on the average of four replications; values in columns followed by the same letter do not differ significantly at $P=0.05$.

\section{RESUMEN}

Intervalos de tiempo y frecuencia óptima para aplicar glifosato en una siembra de plátano (Musa acuminata $\times$ M. balbisiana AAB)

Se realizó un experimento de campo en la Subestación de Corozal donde se evaluaron intervalos de tiempo y frecuencia de aplicación de glifosato para el combate de malezas en plátanos. Con el glifosato al $1 \%$ se logró un mejor desbroce de malezas cuando se acortó el intervalo de aplicación a 6 semanas y se aumentó la frucuencia o número de aplicaciones hasta un máximo de 3 aplicaciones por ciclo de siembra a cosecha. La fiłotoxicidad se incrementó cuando se hicieron varias aplicaciones de glifosało a intervalos de 12 semanas. El mayor número y peso de los plátanos también se obtuvo con 3 aplicaciones de glifosato a un intervalo de 6 semanas. El testigo sin desyerbo fue el que menos y más livianas frutas produjo. A base de los datos obtenidos se determinó que el intervalo de tiempo y la frecuencia óptima para aplicar glifosato en platanales es de 3 aplicaciones a intervalo de 6 semanas. 